\title{
準三次元モデルによる新潟県六日町の地盤沈下予測*
}

\author{
谷中隆明 $* *$ 前川統一郎 $* * *$ 永野多美雄 $* *$
}

\section{An Estimation of the Amount of Land Subsidence at Muika-machi in Niigata Prefecture by a Quasi Thee- dimensional Model ${ }^{*}$}

\author{
Takaaki YANAKA $* *$. Toichiro MAEKAWA $* * *$ Tamio NAGANO**
}

\begin{abstract}
The land subsidence at Muika-machi and its outskirts was analized by a quasi threedimensional model using finete element method. Parameters were decided by geological data, hydraulic data, pumping volume of groundwater, etc. These data were investigated at the site in detail. Calcutated values of hydraulic head and the amount of land subsidence were in good agreement with measured values. An estimation of future subsidence by this model showed that the zone of the large amount of land subsidence will spread over the whole town. This distribution is quite unlike the conventional pattern which showed that maximum subsidence was located in the northern extremity of this town. This change is caused by the latest increase in wells at the center of this town.
\end{abstract}

1. はじめに

20世紀初期以来日本で生じた著しい地盤沈下は、 主に工業用水、農業用水、水道用水あるいは水溶性 天然ガス採取のための地下水の過剩揚水によるもの であった（例えば環境庁水質保全局企画課、1978）。 様々な対策の結果、これらの多くの地域では、1970 年代ころから地盤沈下は鎮静化の傾向をたどってい

*日本地下水学会昭和 63 年度秋季講演会で発表 (1988.10)

**新潟県衛生公害研究所 Niigata Prefectural Research Laboratory for Health and Environment ***国際航業株式会社 Kokusai Kogyo Co. Ltd.
る。しかし、1960年代から本州の日本海側に位置す る豪雪地域では、地下水を散水して融雪するいわゆ る消雪パイプが急速に普及し、最近では、豪雪の冬 期に一部の都市で著しい地盤沈下を生じるように なってきた。新潟県六日町盆地の中心に位置する六 日町もその中の 1 つである。当町では、1975年に水 準測量を開始して以来、1988年現在で累計沈下量の 最大值は $383 \mathrm{~mm}$ を記録している(新潟県環境保健 部公害対策課、1988)。また、1983年 9 月から 1 年 間には、当地域でのこれまでの最高値 $92 \mathrm{~mm}$ の沈下 量を記録した(新潟県生活環境部公害規制課、1985)。 これは、環境庁が昭和59年度に集計した全国の年間 地盤沈下量のうち新潟県上越市の值に次いで第 2 位 
の記録であった。六日町では、市街地の北部及び西 部で建物に数十七ンチメートルの抜け上がりや、著 しいひび割れ等を生じている。しかし、この地域の 地盤沈下解析は、岩田ら（1986）が、ボーリング調 査による採取試料の土質試験をもとに、鉛直 1 次元 モデルを用いて 1 年を 1 パルスとする繰り返し圧密 による地層収縮量の予測計算を 1 地点について実施 しているのみである。そこで、筆者らは、六日町及 びその周辺地区について現地調査による地質・水理 データ、揚水量デー夕等をもとに準三次元モデルに よる地盤沈下予測計算を広範囲に実施し、当地区に おける今後の地盤沈下量分布について新たな知見を 得たので報告する。なお、計算モデルの作成は、前 報（谷中ほか、1989. 以下、前報という）で示した 当地域の諸調查報告及び地下水流動状況に関する定 性的な知見に基づいておこなった。

\section{2. 計算モデル}

\section{1 計算対象地区}

地盤沈下予測計算を行う地区の範囲は、地盤沈下 が顕著に認められる地区（図-1参照）及びその地 区の地下水流動の影響範囲 (前報図-10、図-11参照) 等を考慮して、図一2のように定めた。

\section{2 带水層と加圧層の区分モデル}

加圧層の 3 次元分布については、前報で既に示し た。計算対象地区内で揚水の対象となっている帯水 層は、軟弱地層の分布地区では主にBG1 層、その 他の地区では BG1 層に連続する不圧帯水層である。 BG2 層からの揚水は、わずか 2 本の井戸があるの みで、無視し得る。AG層からの揚水もわずかにあ るが、この带水層については水頭、透水係数等の水 理データが得られていない。そこで、BG1 層上部 の $\mathrm{AC} 1, \mathrm{AG}, \mathrm{AC2}$ の各層をまとめて1つの加圧層と した。また、帯水層はBG1 層1層とし、BG1 層下 部は不透水層とした。以上の地層モデルの模式図を 図一 3 に示す。

\section{3 計算式}

前報で示したように、六日町では降雪期に帯水層 の水頭低下が著しいため、地下水流動を計算するに あたり、帯水層に沿った流ればかりでなく上部の加 圧層を通じた漏水も考慮しなければならない。そこ

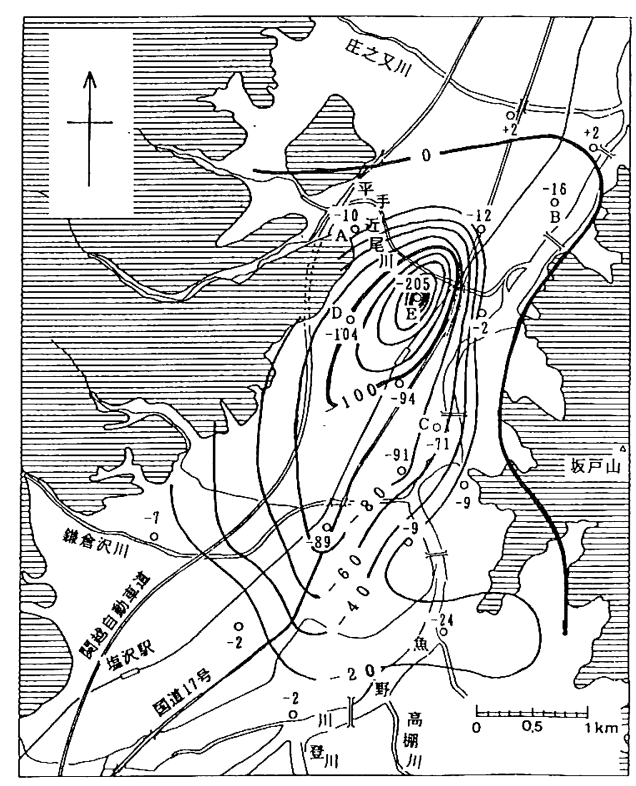

図-1＼cjkstart地盤沈下量分布 (単位 : mm) 1980年 9 月から1985年 9 月

Fig. 1 The distribution of the amount of land subsidenc (unit : $\mathrm{mm}$ )

(from September, 1980 to September, 1985)

で、带水層の地下水流動方程式として漏水を考虑し た準三次元モデル式(Bredehoeft \& Pinder, 1970 ; Shibasaki et al,.1971; 鎌田ほか、1973）を用いるこ とにした。すなわち、

$\mathrm{S}\left(\frac{\partial \mathrm{h}}{\partial \mathrm{t}}\right)=\mathrm{T}\left(\frac{\partial^{2} \mathrm{~h}}{\partial \mathrm{x}^{2}}+\frac{\partial^{2} \mathrm{~h}}{\partial \mathrm{y}^{2}}\right)-\mathrm{Q}-\frac{\mathrm{k}^{\prime}}{\mathrm{b}^{\prime}}(\mathrm{h}-\mathrm{H})$

ここで、 $\mathrm{S}$ : 带水層の貯留係数、 $\mathrm{h}$ : 帯水量の水頭 $\mathrm{t}$ : 時間、 $\mathrm{T}$ : 带水層の透水量係数、 $\mathrm{x}, \mathrm{y}$ : 水平方向 の位置座標、 $\mathrm{Q}$ ：揚水量及び地表からのかん養量、 $\mathrm{k}^{\prime}$ : 加圧層の透水係数、 $\mathrm{b}^{\prime}$ : 加圧層の厚さ、 $\mathrm{H}$ : 不 圧带水層の水位とした。な押、前報によれば加圧層 からの絞り出し量は、当地域の地下水流動量に占め る割合が非常に小さいことから、計算上無視した。 加圧層に扔ける水平方向の地下水流動は、鉛直方向 に比べて一般に非常に小さいことから、加圧層の地 下水流動方程式としてテルッァギーの圧密理論に基 づく鉛直 1 次元モデル式を用いた。すなわち、

$$
\frac{\partial \mathrm{h}^{\prime}}{\partial \mathrm{t}}=\frac{\mathrm{k}^{\prime}}{\mathrm{Ss}^{\prime}}\left(\frac{\partial^{2} \mathrm{~h}^{\prime}}{\partial \mathrm{z}^{2}}\right)
$$

ここで、 $\mathrm{h}^{\prime}$ ：加圧層の間隙水压 $\mathrm{Ss}^{\prime}$ ：加圧層の比貯 留率、 $\mathrm{z}$ : 鉛直方向の位置座標とした。 


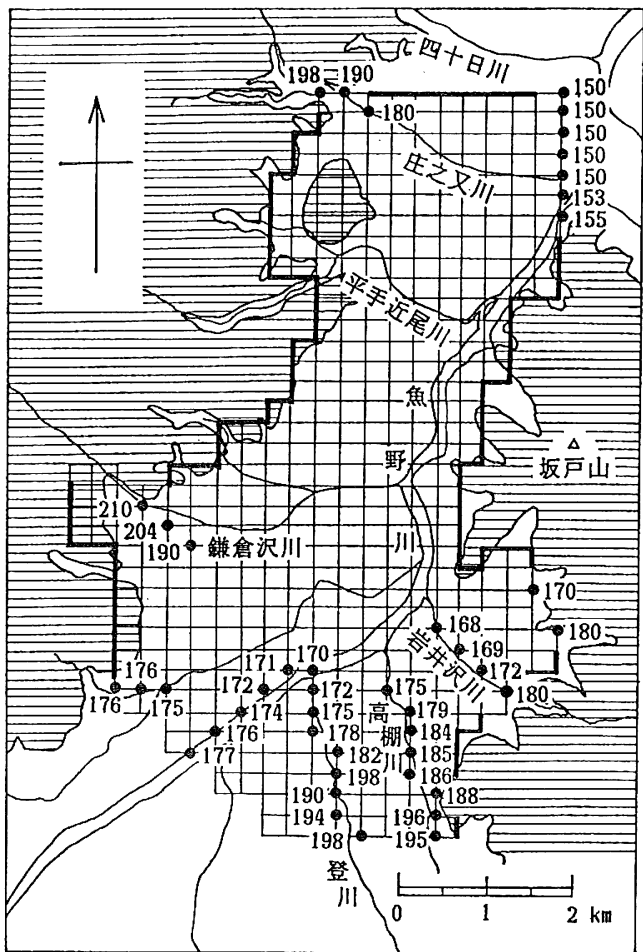

図-2 境界条件及び定水頭節点

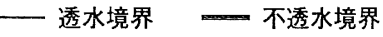

- 定水頭節点 数值 : 水頭 (標高 $\mathrm{m}$ )

Fig. 2 Boundary condition and points of constant hydraulic head - permeable boundary line unpermeable boundary line hydraulic head value : hydraulic head (altitude:m)
以上の式を用いて未知数を求めるための計算手法 として、有限要素法を用いた。な拉、水平方向の要 素分割は、長方形メッシュ（東西約 $278 \mathrm{~m}$ 、南北約 $232 \mathrm{~m})$ を用いた。また、鉛直方向の要素分割は等 間隔で12とした。いずれの計算も、計算時間のステッ プは 1 カ月とした。

加圧層の压密量は、次式からもとめた。

$$
\mathrm{s}=\Sigma \Delta \mathrm{h}_{\mathrm{i}}{ }^{\prime} \cdot \Delta \mathrm{m}_{\mathrm{i}}{ }^{\prime} \cdot \mathrm{S} \mathrm{s}^{\prime}
$$

ここで、 $\mathrm{s}$ : 圧密量、 $\Delta \mathrm{h}_{\mathrm{i}}{ }^{\prime}$ : 間隙水圧变化量、 $\Delta \mathrm{m}_{\mathrm{i}}$ : 層厚とした。

\section{3. 境界条件及び初期条件}

\section{1 境界条件}

带水層の水頭を計算するための境界条件を、図一 2のように定めた。すなわち、東西の山地に沿った 境界は、低地に比べて地下水の流動が一般に非常に 小さいことから不透水層とした。また、北部の境界 は、前報に示したように等水頭線と直交することか ら、不透水層とした。扇状地の扇頂部、登川、高棚 川、岩井沢川等の支流河川及び計算領域の南端及び 北端に位置する魚野川沿いでは、降雪期及び非降雪 期ともに地下水の水頭がほとんど変動しないことか ら、近傍の節点を定水頭とした。定水頭節点と各点 に与えた水頭標高を図ー 2 に示す。

加圧層を通じての漏水量を算定するためには、加 圧層上部の不圧水位が必要である。しかし当地区で は、不圧水位の実測值が得られていない。そこで、 当地区の場合、不压水位は被圧水頭に比べて年間の
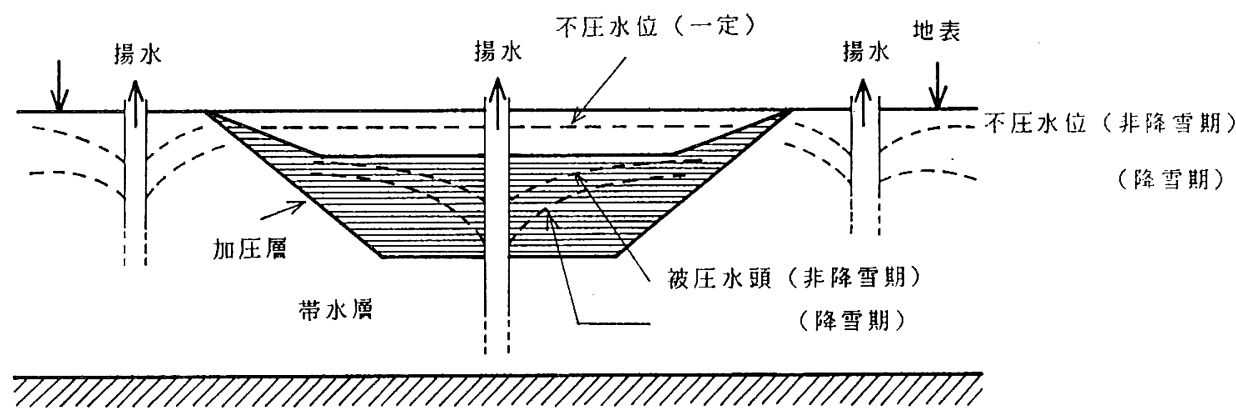

不透水層

図-3＼cjkstart地層及び地下水モデルの概念図

Fig. 3 Outline of layers and a model of groundwater 
変動が小さいと考えられること、また加圧層の連続 性は実際には完全ではないと予想されることから、 不圧水位として非降雪期の BG1 層の水頭（前報図 ー10参照）を用いた。

加圧層の間隙水圧を計算するための境界条件のう ち、加压層上部の境界は前述の不圧水位（定常值） を用い、加圧層下部の境界は(1)式で得られた被圧 帯水層の水頭の計算值を用いた。

\section{2 初期条件}

計算開始年月は、揚水量等のデータが得られた 1980年 4 月とした。計算対象地区の帯水層の水頭は、 降雪期には $10 \mathrm{~m}$ 前後の低下を示すが、非降雪期には 毎年ほとんど同じ水頭に回復する。そこで、計算開 始時における带水層の水頭の地域分布として、一斉 測水調査における非降雪期の測定值を用いた。また、 加圧層の間隙水圧計算を行うにあたり、6 年間のな らし計算を行い、その結果から得られた水圧分布を 1980年 4 月の加压層内の初期閒隙水圧とした。

\section{4. 固定パラメータ}

\section{1 带水層及び加圧層の層厚}

被压带水層の層厚は、前報図-4に示した BG1 層 の層厚分布図によった。また、BG1 層に連続する 不戍带水層については、BG1 層の最大層厚の $60 \mathrm{~m}$ を代入した。加圧層の層厚は、地質柱状図及び電気 検層図から判定した $\mathrm{AC} 1$ 層及び $\mathrm{AC} 2$ 層の層厚の合 計とした。加圧層の層厚分布を図-4 に示す。破線は、 加圧層の分布範囲の境界を示す。加圧層の分布範囲 と六日町市街地の範囲はほぼ一致し、市街地中心部 は上越線と魚野川左岸の間に位置する。加圧層は、 市街地の西部で厚くなる。

\section{2 揚水量及び地表からの地下水かん養量}

揚水量データは、アンケート調査による集計值を もとに1980年 4.月から1986年 3 月までの BG1 層に ついての算定値を用いた（前報参照）。

地表からの地下水かん養源としては、降雨、融雪 水及び水田等の灌がい水がある。融雪水量は、気温 上昇に伴う融雪及び積雪上への降雨による融雪を考 慮して、日降水量及び気温のデータをもとに計算し た。降雨、融雪水及び灌がい水による地下水かん養 量は、角屋ら（1967）による補給能モデルによって

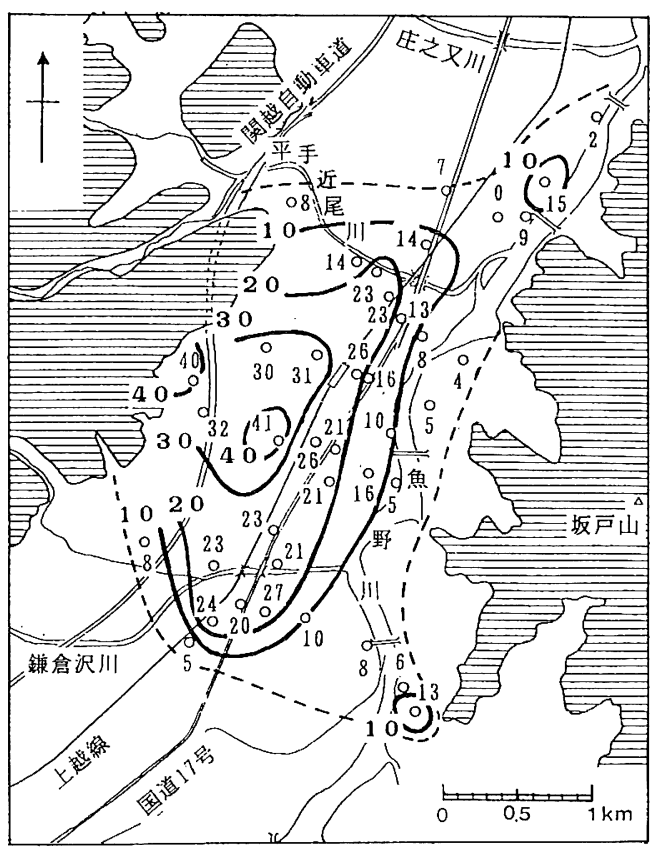

図-4 加圧層の層厚分布 (単位 : $m$ ) - - 加圧層の分布境界

Fig. 4 Distribution of the thickness of confining layers (unit:m) - - outline of confining layers

計算した。なお、加圧層が分布する地区では、地表 からの地下水かん養は無いものとした。補給モデル で地下水かん養量を計算するには、上限補給能 $(\mathrm{fu})$ 、

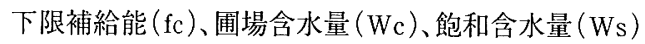
及び初期含水量（Wo）が必要である。しかし、当 地域ではこれらの諸量を実測していないので、関東 北部における値（環境庁水質保全局企画課、1984） $\mathrm{fu}=0.80 \mathrm{~mm} / \mathrm{hr}, \mathrm{fc}=0.30 \mathrm{~mm} / \mathrm{hr}, \mathrm{Wc}=25 \mathrm{~mm}, \mathrm{Ws}=$ $60 \mathrm{~mm}, \mathrm{Wo}_{\mathrm{O}}=25 \mathrm{~mm}$ を用いた。な㧍、調查対象地区 では、平地に占める水田の割合は約 $37 \%$ ある。そ こで、調查地域の各メッシュ毎に水田が37\%分布す るものとして、この地区では、灌がい期 $(4 \sim 8$ 月) に土壤の含水量が常に國場含水量に保たれるとし た。また、地表からの可能蒸発散量は、 Thornthwaite 法（例えば山本、1983，pp.297-298） によって求めた。

降雨、融雪水及び灌がい水として地表に供給され た水を前述の計算方法に基ついて地下水かん養量、 直接流出量、蒸発散量に分け、1980年 4 月から1986 年 3 月までの 6 年分について毎月の值を求めた。そ 
の結果、年間の地下水かん養量は 6 年間の平均で約 $560 \mathrm{~mm}$ であった。この值は、年䦗降水量の 6 年問 の平均値 $2797 \mathrm{~mm}$ の $20 \%$ に相当する。また、年間の かん養量を 1 日平均值に換算すると $1.6 \mathrm{~mm}$ であり、 この值は、金子（1973）による新潟平野各地域の地 下水水収支の值と同程度である。地下水かん養量は、 融雪水と灌がい水の雨面からの供給により、每:年 4 月前後に最大値に達する。融雪期（3，4，5月）の 地下水かん養量は、年問値の $50 \%$ に達する。一方、 地下水の需要が飛躍的に増大寸る皦冬期 $(1 ， 2$ 月) の地下水かん養量は、年問の地下水かん養量の $4 \%$ に満たない。

\section{5. 内挿検定による諸パラメータの決定}

\section{1 带水層の水頭分布計算のための内挿検定}

带水層の透水係数は、BG1 層の透水係数分布図 （前報図- 5 参照）から読み取った值を暂定値とし た。内挿検定の結果、带水層の透水係数の最終的な 值は、暫分值に対し最大で 5 倍の修正值に留まった。 加压:層の透水係数は、 $5 \times 10^{-2} \mathrm{~m} / \mathrm{day}\left(5.8 \times 10^{-}\right.$ $\left.{ }^{7} \mathrm{~m} / \mathrm{s}\right)$ として一律に与えた。これはシルト並の值 であり、粘土の一般的な值の約1,000倍に相当する 非常に大きな值である（Freeze \& Cherry, 1979)。 眝留係数は被压带水層の場合、比貯留率と層厚の積 として与えられる。比眝留率は、 $5 \times 10^{-1} 1 / \mathrm{m}$ を 一律に与えた。この值は、砂層の一般的な值に比べ て、10倍から数十倍大きな值である(Domenico \& Mifflin, 1965)。不圧带水層の貯留係数は、地層の有 効間隙率に等しい。有効間隙率としては、砂れきの 一般的な值0.16を一律に与えた（山本、1983,13p.)。

以上の諸パラメータ及び 4 で述べた固定パラメー 夕を用いて、1980年 4 月から1986年 3 月までの 6 年 間について、带水層の水頭の計算值と実測值を比較 した結果を図- 5 及び网- 6 に示す。実測值は、前報 の図-10及び図-11に示した一斎測水による值であ る。水頭の地域分布について、計算値と実測值は概 ね良く一致している。また、図-7に、市街地中央 部にある六日町 1 号井 (六日町役場前) の実測值と 計算値の時系列变化の比較を示す。他に、調査地域 内の 3 井についても実测值と計算値の比較を行った が、六日町 1 号井同様、両者は非常によく一致した。 これらの結果から、带水層の地下水流動に関する当 計算のモデルは、ほぼ妥当と考えられる。

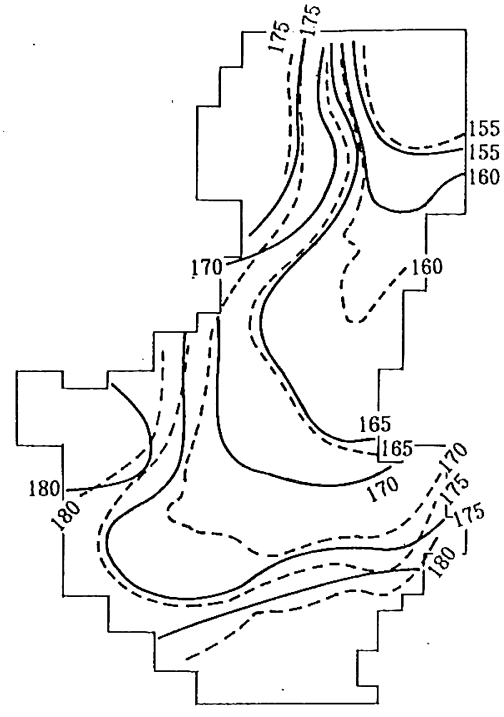

图-5 計算水頭と実測水頭の分布比較（1985年11月） 一計算值 - - 実測值

Fig. 5 Comparison of distributions between calculated hydraulic head and measured hydraulic head (November, 1985)

- calculated . - - - measured

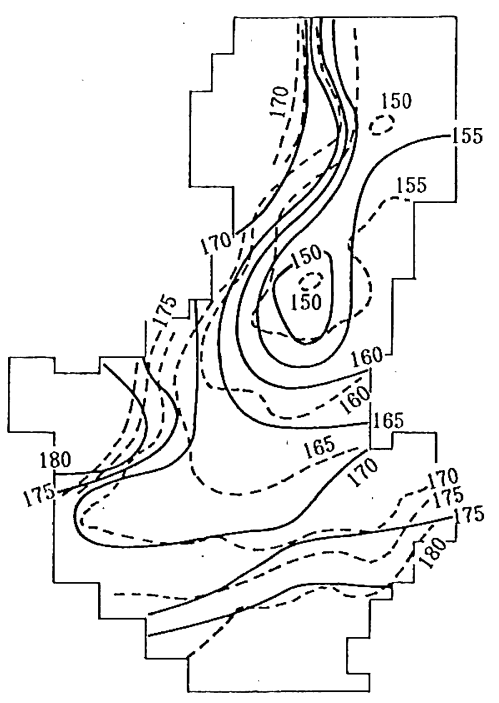

図-6 計算水頭と実測水頭の分布比較（1986年 1 月）

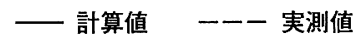

Fig. 6 Comparison of distributions between calculated hydraulic head and measured hydraulic head (November, 1986)

- calculated - - measured 


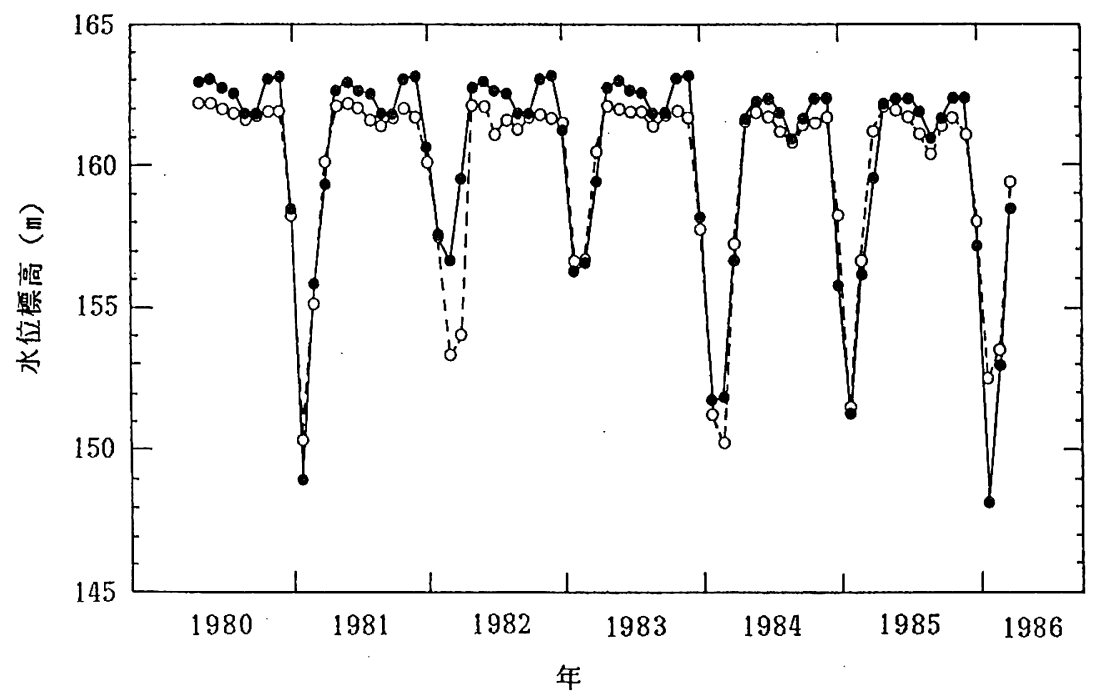

図-7＼cjkstart観測井水位についての計算値と実測値の比較

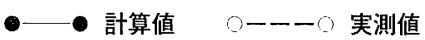

Fig. 7 Comparison of water level in a observation well between calculated value and measured value

calculated

O- - $\bigcirc$ measured

なお、上記のモデルでは、加圧層の透水係数とし て非常に大きな值が与えられている。しかし、次項 に示すように、加圧層の収縮量計算の際には、加圧 層の透水係数として粘土層の一般的な值を与えて内 挿検定で良好な結果を得ている。このことは、加圧 層に透水性の大きな部分があることを示唆する。そ の例として、前報でも述べたように、AC2 層の不 連続部分、あるいは AC2 層を貫通している約 2,000 本の井戸と地層との間隙等が考えられる。

\section{2 加圧層の収縮量計算のための内挿検定}

加圧層にかかる有効応力が圧密降状応力以上のと き、加圧層の透水係数及び比貯留率を、それぞれ Freeze \& Cherry（1979）及びDomenico \& Mifflin (1965)による粘土層の值の範囲内で設定した。また、 市街地中央部にある観測井の地層収縮量記録によれ ば、 $\mathrm{BG} 1$ 層の水頭が上昇するとき $\mathrm{BG} 1$ 層上部の加 圧層にわずかながら膨張が認められることから、加 圧層にかかる有効応力が圧密降伏応力以下のとき、 比貯留率を前者の $1 / 10$ とした。各水準点における年 間地盤沈下量実測值とその地点に扔ける加圧層の年 間収縮量の計算值の比較結果の一部を、図- 8 に示 す。両者は非常に良く一致している。また、同じく
計算を行った他の 8 地点の水準点についても、実測 值と計算值は、四- 8 と同様に非常に良く一致した。 近年、最も地盤沈下が著しかった1984年の揚水実績 に基づく年間地盤沈下量の計算値を、図- 9 に示す。 最大沈下地点は、市街地の北端に位置する。

\section{6. 地盤沈下量分布の予測}

\section{1 揚水量の設定条件}

降雪期に扔ける六日町の地下水揚水量は、大部分 が消雪用であるため、揚水量は降雪量によって大き く左右される。そこで、消雪用以外の用途の揚水量 は1986年の值を用い、消雪用のみを降雪の条件に応 じて変化させた。

前報で示したように、筆者らは消雪用地下水の揚 水量を

揚水能力 $\left(\mathrm{m}^{3} / \mathrm{hr}\right) \times$ 揚水ポンプ稼働係数 $(\mathrm{hr} / \mathrm{cm})$ $\times$ 日降雪量の月間累計値 $(\mathrm{cm})$

から求めている。そこで、揚水能力は1986年 3 月現 在のものを用い、降雪量のデータは(1)1980年から 1986年までの平均值（累計 $1,432 \mathrm{~cm}$ ) (2)近年最大の 豪雪であった1983年12月から1984年にかけてのもの （累計 $1,910 \mathrm{~cm}$ ) を用いて、2 通りの消雪用地下水 


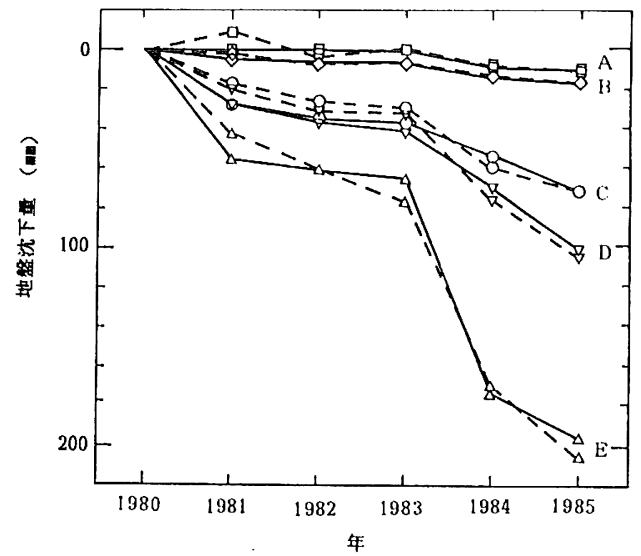

図-8 各水準点の地盤沈下量についての計算値と実測値の 比較

基準：1980年 9 月 一 計算値 - - 実測值

点 A, B, C, D, E, の位置は図 1 に示す。

Fig. 8 Comparison of the amount of land subsidence at each bench-mark between calculated value and measured value

starting point : November,1980

- calculated _- measured

Locations of A, B, C, D and E are shown in Fig. 1

揚水量の設定値とした。

\section{2 予測計算結果}

前項で示した揚水量の条件(1)及び(2)の場合の計算 結果を、それぞれ図-10及び図-11に示す。図-9の 地盤沈下量分布のパターンと比較すると、いずれも 沈下量が最大である地点が南下し、さらに広域化し ている。特に、揚水条件(2)の場合は、地盤沈下量 $70 \mathrm{~mm}$ を超える地区が市街地のほぼ全域に及ぶこと を示している。このような結果が得られた理由とし ては、1984年の豪雪以降、六日町の市街地中央部で 井戸の新設が相次ぎ、揚水能力が年間で約 $30 \%$ 増加 した一方、従来、最大沈下量を示していた地点は、 3\%の増加に留まったことがあげられる。したがっ て、今後節水等により揚水量の抑制を図らなければ、 豪雪の年には現在よりも広域で大きな地盤沈下を生 じる恐れがある。特に、市街地の西部は、軟弱な加 圧層が最も厚く、しかも水田から宅地へと移り変わ り始めたばかりで、圧密が進んでいないと予想され ることから、今後の推移が注目される。

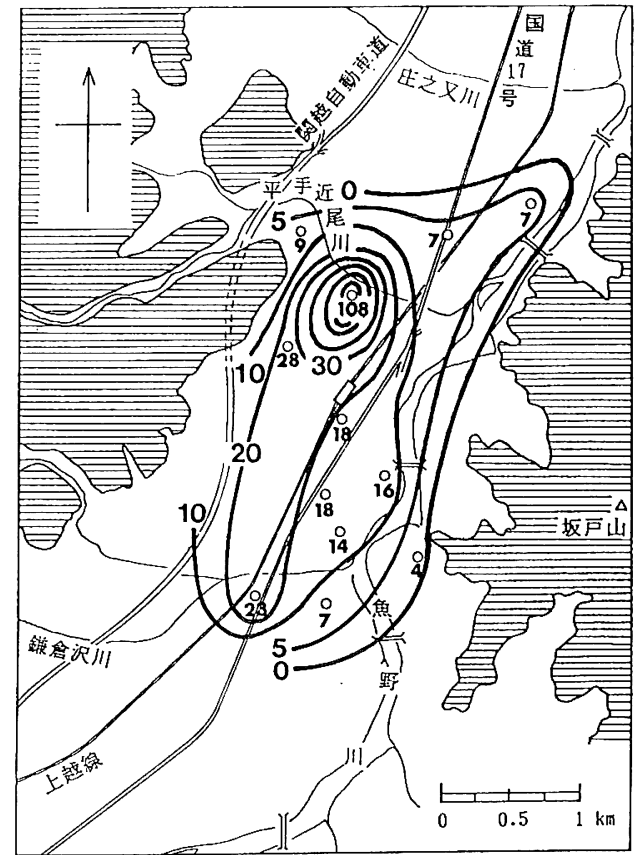

図-9 実揚水量による年間地盤沈下量計算値 1983年 9 月から1984年 9 月； mm

Fig. 9 The amount of land subsidence in a year which is calculated from practical pumping volume from November, 1983 to November, $1984 ; \mathrm{mm}$

\section{7. おわりに}

以上の解析によって、次のことが明らかになった。 (1)六日町及びその周辺地区について現地調査によ る地質・水理デー夕、揚水量デー夕等をもとに、準 三次元モデルを用いて、有限要素法による地盤沈下 シミュレーションを行った。带水層の水頭及び地盤 沈下量の分布について、計算值は実測值と良く一致 したことから、モデル及び諸パラメータの設定は適 切であったと考えられる。

（2）当モデルを用いて、今後の地盤沈下量分布を予 測したところ、地盤沈下量分布のパターンは、従来 市街地の北端に最大值があったものと大きく異な り、地盤沈下量の大きい地域が市街地中央部全体に 広がる結果が得られた。そのため、今後、揚水量を 抑制する対策を講じなければ、従来と同じ降雪量で も従来よりも大きな地盤沈下を生じることが予想さ れる。

（3）市街地の西部は、次第に宅地化されているが、 


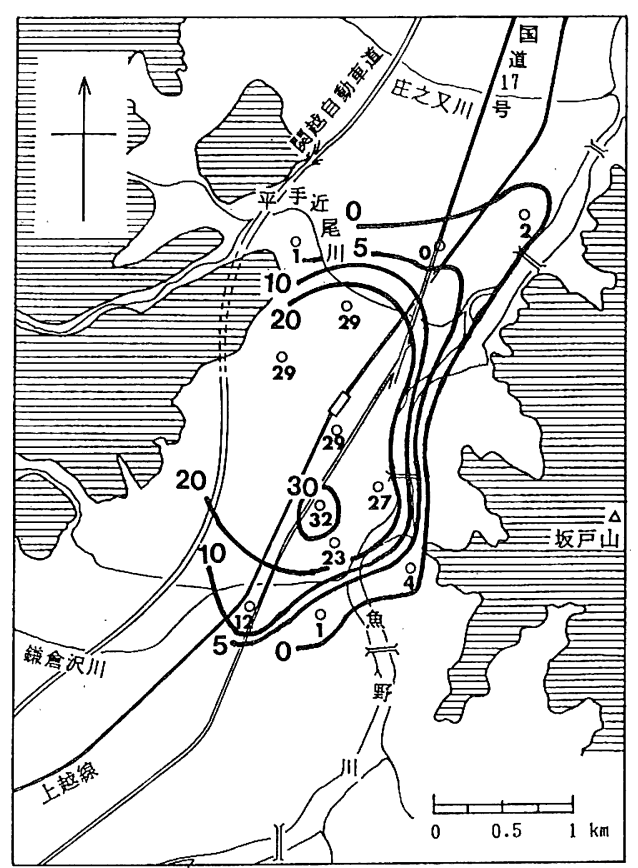

図-10 地盤沈下量予測 (I)

揚水能力：1985年 4 月から1986年 3 月

降雪量：1980年から1986年までの平均值

Fig. 10 Estimation of the amount of land subsidence (1) rate of pumping volume : from April, 1985 to March, 1986 snow fall : avarage of 1980 to 1986 snow fall : average of 1980 to 1986

圧密が進んでいないと予想される軟弱な加圧層が最 も厚く分布することから、今後の推移が注目される。

\section{謝 辞}

当解析を進めるにあたり、解析の機会を与えてい ただいた新潟県環境保健部公害対策課長をはじめ担 当者の方々、ご指導をいただいた新潟県衛生公害研 究所大山征也環境科学科長、国立公害研究所水質土 壤環境部陶野郁雄博士、新潟大学積雪地域災害研究 センター青木 滋教授に感謝します。

\section{参 考 文 献}

岩田敏・陶野郁雄・桑田文大（1986）：新潟県六日町に 打ける消雪用揚水に伴う地盤沈下とその解析、土と基碟、 34-11, 73 78.

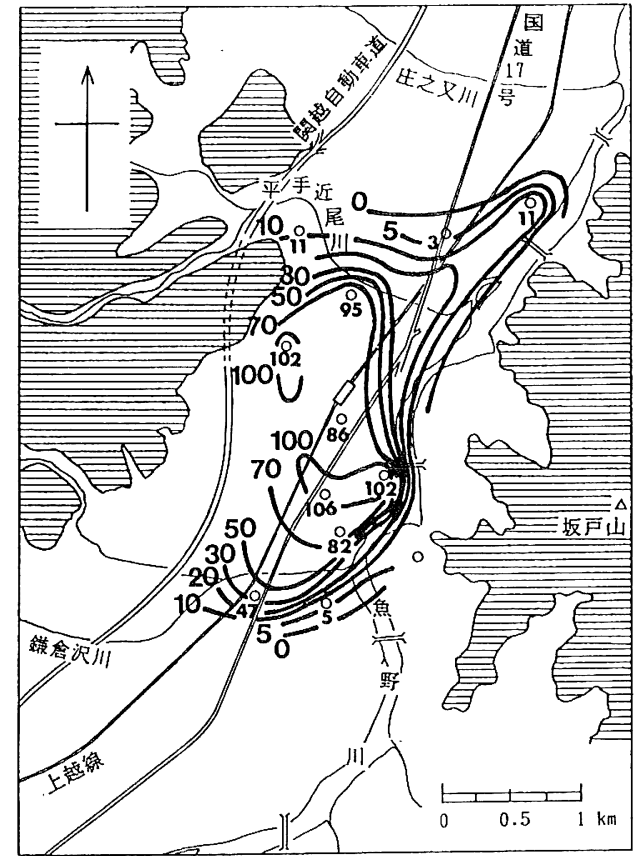

図-11 地盤沈下量予測 (II)

揚水能力：1985年 4 月から1986年 3 月

降雪量 $\quad$ :1983年12月から1984年 3 月

Fig. 11 Estimation of the amount of land subsidence (2) rate of pumping volume : from April, 1985 to March, 1986 snow fall : December, 1983 to March, 1984

角屋 睦・豊国永次・丈達俊夫（1967）：山地小流域河川 の低水位解析 (2)、京大防災研年報，10-B，147 154.

金子 良 (1973)：「水文学講座12.農業水文学」共立出版、 202 212.

鎌田 烈- 村上雅博 - 原田和彦（1973）：準三次元带水層 モデルによる地盤沈下の解析、地球科学, 27-4, 131〜 140.

環境庁水質保全局企画課（1978）：「公害と防止対策 地 下水と地盤沈下対策」、白亚書房、8 46.

環境庁水質保全局企画課（1984）：「昭和58年度 関東平 野北部地域地盤沈下広域対策調查報告書」、132p.

新潟県生活環境部公害規制課（1985）：「南焦沼地区の地 盤沈下 $(9) 」 ， 16 \mathrm{p}$.

新潟県環境保健部公害対策課（1988）：「南魚沼地区の地 盤沈下 $(12) 」, 20 \mathrm{p}$.

谷中隆明 - 永野多美雄 - 山㠃興樹 - 水谷宣明（1989）：新 潟県六日町盆地の地下水流動、地下水学会誌 31-3, 
143 153.

山本荘毅（1983）：「新版地下水調査法」、古今書院, 13p., $297 \sim 298$.

Bredehoeft, J.D. and G.F.Pinder (1970) : Digital Analysis of Areal Flow in Multiaquifer Groundwater Systems - a Quasi Three-dimensional Model -. Water Resources Research, 6-3, 883 888 .

Domenco, P.A. and M.D.Mifflin (1965) : Water from Lowpermeability Sediments and Land Subsidence. Water Resoureces Research, 1-4, 563 576.

Freeze, R.A. and J.A. Cherry (1979) : Groundwater. Prentice-Hall New Jersey, 29p.

Shibasaki, T., A. Kamata and M. Wada (1971) : Application of the Water Balance Simulation for Predicting Land Subsidence - a Digital Computer Approach -. IAH Memories, 9, $1-97$.

(受付：1989年 3 月 1 日、受理：1989年 5 月 29 日)

\section{和 文 要 約}

六日町及びその㓮辺地区について、準三次元モデ ルを用いて有限要素法による地盤沈下解析を行っ た。パラメー夕は、現地での詳細な調査による地 質・水理デー夕、揚水量デー夕等をもとに決定さ れた。帯水量の水頭及び地盤沈下量の分布につい て、計算値は実測值と良く一致した。当モデルを 用いて今後の地盤沈下量分布を予測したところ、 地盤沈下量分布のパターンは、地盤沈下量の大き い地域が市街地中央部全体に広がる結果が得られ た。この分布は、従来市街地の北端に最大值があっ たものと大きく異なる。この変化は、最近の市街 地中央部での井戸の增加に起因している。 